ARTICLE

Received 16 Apr 2014 | Accepted 15 Dec 2014 | Published 4 Feb 2015

DOI: $10.1038 /$ ncomms7096

OPEN

\title{
Total synthesis and antiviral activity of indolosesquiterpenoids from the xiamycin and oridamycin families
}

\author{
Zhanchao Meng ${ }^{1}$, Haixin $\mathrm{Yu}^{1}$, Li Li ${ }^{2}$, Wanyin Tao ${ }^{2}$, Hao Chen ${ }^{1}$, Ming Wan ${ }^{1}$, Peng Yang ${ }^{1}$,
}

David J. Edmonds ${ }^{3}$, Jin Zhong ${ }^{2} \&$ Ang $\mathrm{Li}^{\mathrm{i}}$,4

Indolosesquiterpenoids are a growing class of natural products that exhibit a wide range of biological activities. Here, we report the total syntheses of xiamycin $A$ and oridamycins $A$ and $B$, indolosesquiterpenoids isolated from Streptomyces. Two parallel strategies were exploited to forge the carbazole core: $6 \pi$-electrocyclization/aromatization and indole $\mathrm{C} 2-\mathrm{H}$ bond activation/Heck annulation. The construction of their trans-decalin motifs relied on two diastereochemically complementary radical cyclization reactions mediated by $\mathrm{Ti}(\mathrm{III})$ and $\mathrm{Mn}(\mathrm{III})$, respectively. The $\mathrm{C} 23$ hydroxyl of oridamycin B was introduced by an $\mathrm{sp}^{3} \mathrm{C}-\mathrm{H}$ bond oxidation at a late stage. On the basis of the chemistry developed, the dimeric congener dixiamycin $C$ has been synthesized for the first time. Evaluation of the antiviral activity of these compounds revealed that xiamycin $A$ is a potent agent against herpes simplex virus-1 (HSV-1) in vitro.

\footnotetext{
${ }^{1}$ State Key Laboratory of Bioorganic and Natural Products Chemistry, Shanghai Institute of Organic Chemistry, Chinese Academy of Sciences, 345 Lingling Road, Shanghai 200032, China. ${ }^{2}$ Unit of Viral Hepatitis, Key Laboratory of Molecular Virology and Immunology, Institut Pasteur of Shanghai, Shanghai Institutes for Biological Sciences, Chinese Academy of Sciences, Shanghai 200032, China. ${ }^{3}$ Pfizer Worldwide Research and Development, Cambridge, Massachusetts 02139, USA. ${ }^{4}$ Collaborative Innovation Center of Chemistry for Life Sciences, 22 Hankou Road, Nanjing, Jiangsu 210093, China.

Correspondence and requests for materials should be addressed to A.L. (email: ali@sioc.ac.cn).
} 
ndolosesquiterpenoids have attracted increasing attention from chemical and biosynthetic perspectives ${ }^{1-7}$; however, their biological activities are yet to be systematically explored through chemical synthesis ${ }^{8-14}$. Xiamycin A (1, Fig. 1), isolated independently from Streptomyces species by Hertweck ${ }^{15-18}$ and Zhang ${ }^{19-21}$, displays selective anti-HIV activity. The naturally occurring antibiotics oridamycins $\mathrm{A}$ and $\mathrm{B}$ (2 and 3 ) share a similar scaffold to that of $\mathbf{1}$, though with the opposite stereochemistry at quaternary $\mathrm{C} 16$ (ref. 22). Several congeners of 1 were also identified from the same species, including the C6$\mathrm{N}^{\prime}$ dimer dixiamycin $\mathrm{C}(4)$, the $\mathrm{C} 11-\mathrm{C} 12$ bond oxidized and ring-expanded oxiamycin (5) and a putative biosynthetic precursor, indosespene $(6)^{17-21}$. Considerable efforts have been made towards revealing the biogenesis of this class of natural products, including the elucidation of the relevant gene clusters and enzymes ${ }^{17-20}$. The chemical synthesis of these compounds $^{13,14}$ may help further the understanding of the biosynthetic relationships within this indolosesquiterpenoid family, as well as the discovery of their unknown biological activities. Very recently, Baran et al. ${ }^{13}$ disclosed the first total synthesis of xiamycin A (1) and dixiamycin B.

In this paper, we report the total syntheses of xiamycin $A$, oridamycins $A$ and $B$, dixiamycin $C(\mathbf{1 - 4})$ and indosespene (6). The syntheses of 2-4 were accomplished for the first time. A $6 \pi$ electrocyclization strategy and an oxidative Heck annulation strategy were developed for assembling the carbazole scaffold. The antiviral properties of the synthetic natural products were evaluated in vitro, and $\mathbf{1}$ exhibits potent inhibitory activity against herpes simplex virus-1 (HSV-1).

\section{Results}

Retrosynthetic analysis. The synthetic challenge of the xiamycin and oridamycin families may be separated into two distinct problems, namely the stereocontrolled assembly of the transdecalin motif bearing the C16 quaternary centre and the construction of the carbazole core. Inspired by the structural correlation between xiamycin A (1) and indosespene (6), our retrosynthetic analysis of 1 (Fig. 2) began with a disconnection at the $\mathrm{C} 2-\mathrm{C} 21$ bond. A $6 \pi$-electrocyclization ${ }^{23}$ (path a) and a

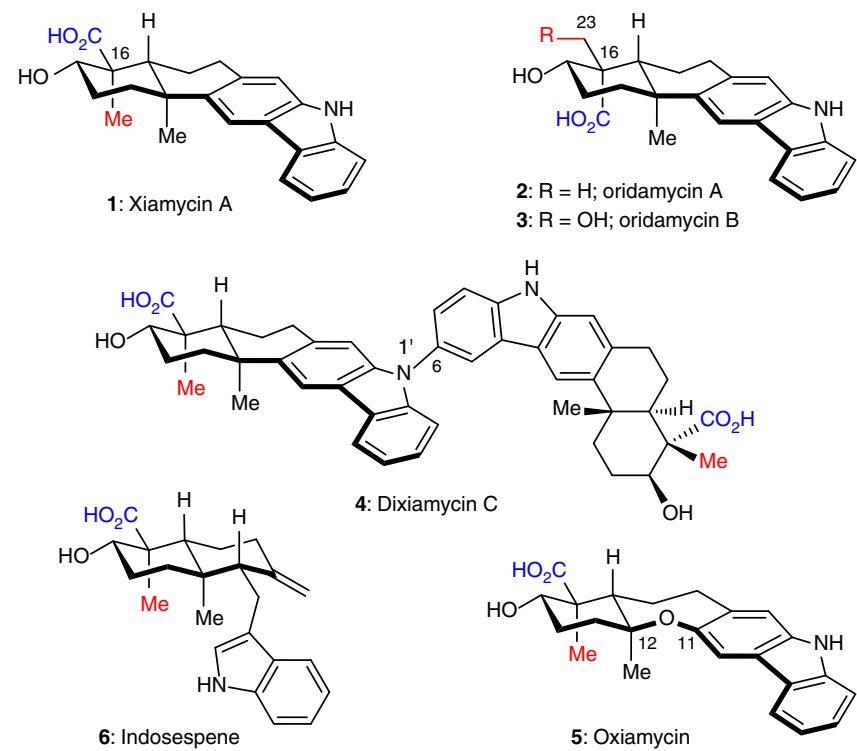

Figure 1 | The structures of representative natural products from the xiamycin and oridamycin families. The two families share a similar scaffold but differ in the C16 stereochemistry. Indosespene (6) is a putative biosynthetic precursor of xiamycin $A(\mathbf{1})$.
Heck-type annulation ${ }^{24-29}$ (path b) were envisioned as two alternatives to forge the carbazole motif. The former draws on our recent syntheses of tubingensin $\mathrm{A}$ and daphenylline $\mathrm{e}^{30,31}$, while the latter relies on activation of the indole $\mathrm{C} 2-\mathrm{H}$ bond by palladium. Correspondingly, triene (7) and indosespene ester (8) are considered as the key intermediates for the two strategies. These functionalized decalin systems are expected to arise from a cascade cyclization of dienylepoxide precursors, such as $\mathbf{9}$ and $\mathbf{1 0 .}$ This type of radical cyclization may be initiated by reduction of the epoxide by a $\mathrm{Ti}(\mathrm{III})$ species $^{32-47}$, although, to our knowledge, $\alpha, \beta$-epoxy esters/ketones have not been fully explored as the substrates for such cyclization ${ }^{14,48}$. Notably, Cuerva and coworkers $^{49}$ disclosed that enol radicals derived from $\alpha, \beta$ unsaturated ketones inhibit the cyclization reaction. The stereochemical outcome of the cyclization cascade (including the stereochemistry at C16) would be determined by the chirality and geometry of the precursor, which may allow a convenient access to oridamycins A and B (2 and 3) from an alternative precursor. Successful execution of the route outlined above would also be anticipated to provide access to indosespene (6) and dixiamycin C (4) through minor modifications.

The $6 \pi$-electrocyclization/aromatization approach. Fig. 3 illustrates the $6 \pi$-electrocyclization/aromatization approach for the synthesis of xiamycin A (1). Starting from optically active epoxide $11(96 \% \text { ee })^{50}$, a sequence of 2 -azaadamantane $N$-oxyl (AZADO) oxidation $^{51,52}$ and esterification led to compound 12 in $76 \%$ overall yield. On the basis of seminal work on the Ti(III)catalysed bioinspired epoxypolyene cyclization by Cuerva and Oltra $^{38-41}$, we investigated the cyclization of the $\alpha, \beta$-epoxy ester 12. Under the optimized conditions $\left[\mathrm{Cp}_{2} \mathrm{TiCl}_{2}(20 \mathrm{~mol} \%), \mathrm{Mn}\right.$, $i \mathrm{Pr}_{2} \mathrm{NEt}$, TMSCl], the desired trans-decalin 13 was obtained as a single diastereomer. TBS protection followed by acetyl deprotection gave 14 (44\% yield for the three steps), which was subjected to a sequence of DMP oxidation, Grignard addition (with reagent 15$)^{30}$, and dehydration $\left(\mathrm{MsCl} / i \mathrm{Pr}_{2} \mathrm{NEt}\right)$ to furnish triene 16 in $75 \%$ overall yield. On microwave irradiation $\left(120^{\circ} \mathrm{C}\right.$, air), 16 underwent a thermal $6 \pi$-electrocyclization and a subsequent aromatization to generate carbazole $\mathbf{1 7}$ (80\% yield). Similarly, when using Grignard reagent 18 with a bromine substituent, we readily obtained compound 19 via the corresponding triene 20. This bromocarbazole served as an

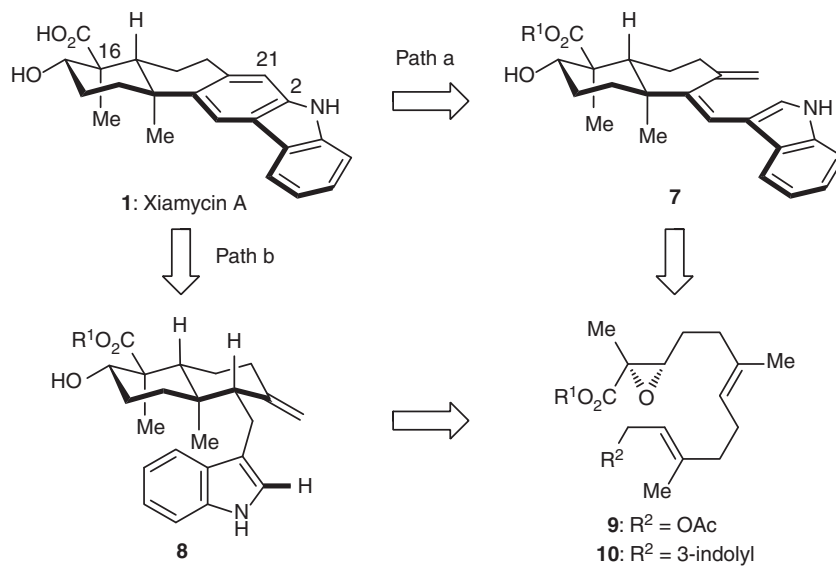

Figure 2 | Two retrosynthetic analyses of xiamycin A. One (path a) features a $6 \pi$-electrocyclization/aromatization strategy, and the other (path b) involves an indole $\mathrm{C} 2-\mathrm{H}$ bond activation/Heck annulation strategy. The devised strategies are anticipated to be applicable to the synthesis of other members from the xiamycin and oridamycin families. 

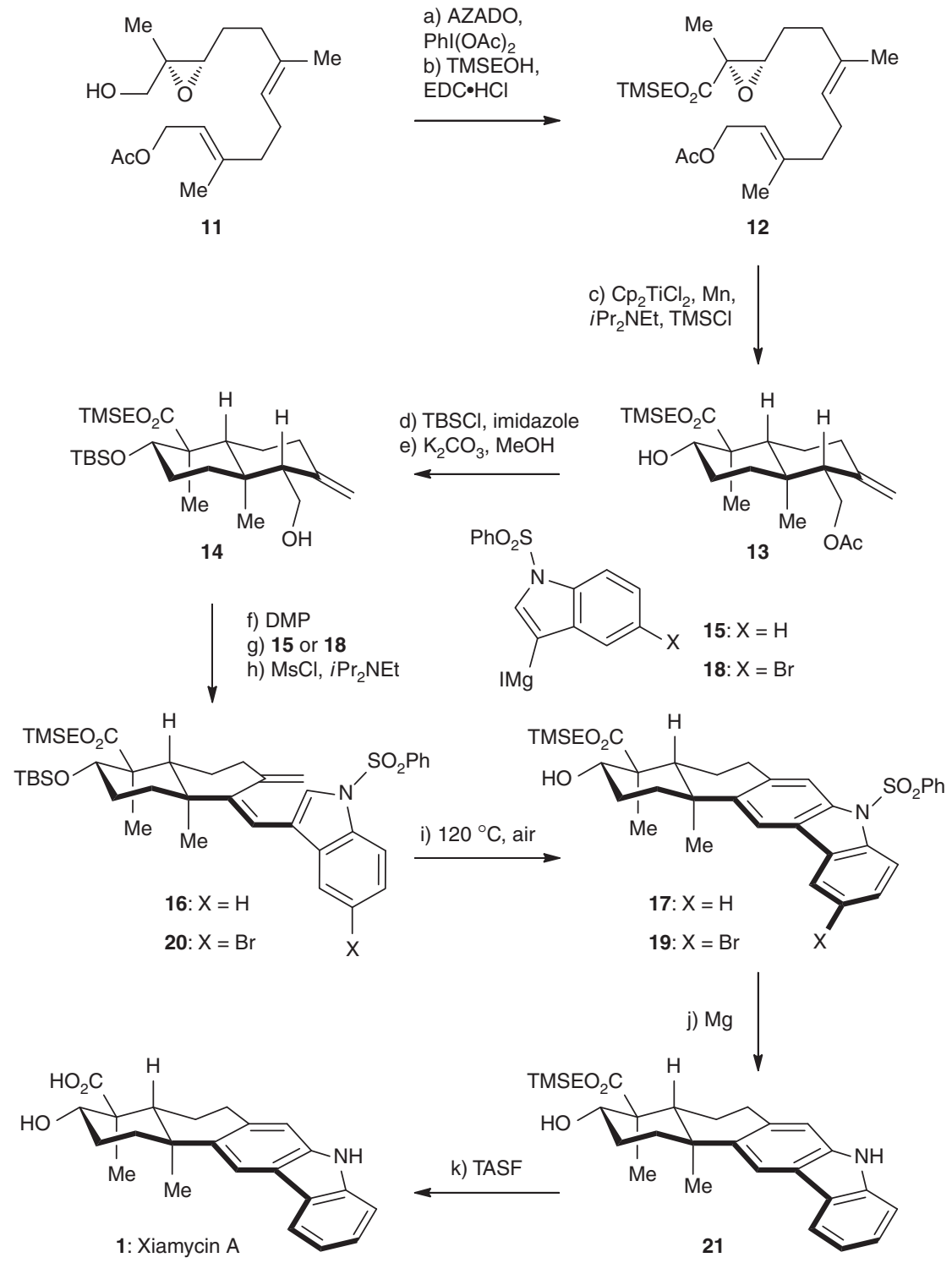

Figure 3 | The $\mathbf{6} \pi$-electrocyclization/aromatization approach towards the total synthesis of xiamycin A. Reagents and conditions: (a) AZADO (5 mol\%), Phl(OAc) 2 (3.0 eq), $\mathrm{CH}_{2} \mathrm{Cl}_{2}, 22^{\circ} \mathrm{C}, 6 \mathrm{~h}$; (b) TMSEOH (1.2 eq), EDC•HCl (1.1 eq), 4-DMAP (1.0 eq), $\mathrm{CH}_{2} \mathrm{Cl}_{2}, 22^{\circ} \mathrm{C}, 5 \mathrm{~h}, 76 \%$ (two steps); (c) $\mathrm{Cp}_{2} \mathrm{TiCl}_{2}(20 \mathrm{~mol} \%), \mathrm{Mn}(8.0 \mathrm{eq}), \operatorname{Prr}_{2} \mathrm{NEt}(6.0 \mathrm{eq}), \mathrm{TMSCl}(5.0 \mathrm{eq}), \mathrm{THF}, 22^{\circ} \mathrm{C}, 4 \mathrm{~h}$; (d) $\mathrm{TBSCl}(1.2 \mathrm{eq})$, imidazole $(1.5 \mathrm{eq}), \mathrm{DMF}, 22^{\circ} \mathrm{C}, 10 \mathrm{~h} ;(\mathrm{e}) \mathrm{K}_{2} \mathrm{CO}_{3}$ (1.0 eq), MeOH, $22^{\circ} \mathrm{C}, 3 \mathrm{~h}, 44 \%$ (3 steps); (f) DMP (1.5 eq), $\mathrm{CH}_{2} \mathrm{Cl}_{2}, 22^{\circ} \mathrm{C}, 30 \mathrm{~min}$; (g) 15 or 18 (3.0 eq), $\mathrm{THF}^{\circ} 22^{\circ} \mathrm{C}, 40 \mathrm{~min} ;(\mathrm{h}) \mathrm{MsCl}(1.2 \mathrm{eq}), \operatorname{Pr}_{2} \mathrm{NEt}$ (1.5 eq), $\mathrm{CH}_{2} \mathrm{Cl}_{2}, \mathrm{O}^{\circ} \mathrm{C}, 1 \mathrm{~h}, 75 \%$ for $\mathbf{1 6}$ (three steps), $71 \%$ for $\mathbf{2 0}$ (three steps); (i) air, DMSO, $120^{\circ} \mathrm{C}, 2 \mathrm{~h}, 80 \%$ for $\mathbf{1 7}, 76 \%$ for $\mathbf{1 9}$; (j) $\mathrm{Mg}(2.0 \mathrm{eq}$ ), $\mathrm{MeOH}, 22^{\circ} \mathrm{C}, 1 \mathrm{~h}, 98 \%$; (k) TASF (2.0 eq), DMF, $50{ }^{\circ} \mathrm{C}, 95 \%$.

appropriate substrate for the crucial $\mathrm{C}-\mathrm{N}$ bond formation in our dixiamycin $\mathrm{C}$ synthesis (vide infra). Desulfonylation of $\mathbf{1 7}$ followed by TMSE deprotection of the resulting compound $\mathbf{2 1}$ afforded xiamycin A (1) in a good overall yield, the structure of which was confirmed by X-ray crystallographic analysis (Fig. 4).

The mechanism of the cascade cyclization is postulated in Fig. 5. The epoxide $\mathrm{C} 16-\mathrm{O}$ bond is reductively cleaved by the $\mathrm{Ti}$ (III) species to generate 22, which triggers two sequential cyclization reactions, and the resulting radical 23 could undergo a mixed disproportionation ${ }^{53}$ to give the intermediate 24 with an exocyclic $\mathrm{C}=\mathrm{C}$ bond. In fact, two side reactions occurred: 1 , over reduction of 22 to the corresponding enolate ${ }^{48}$ followed by $\beta$-elimination to form an $\alpha, \beta$-unsaturated ester; 2 , hydrogen transfer to $\mathbf{2 3}$ to form the saturated derivative of $\mathbf{2 4}$. Organic bases had subtle influence on these undesired reactions 54 , and $i \mathrm{Pr}_{2} \mathrm{NEt}$ was found to suppress the latter effectively in our case. Considering the challenges for the acid-promoted epoxy polyene
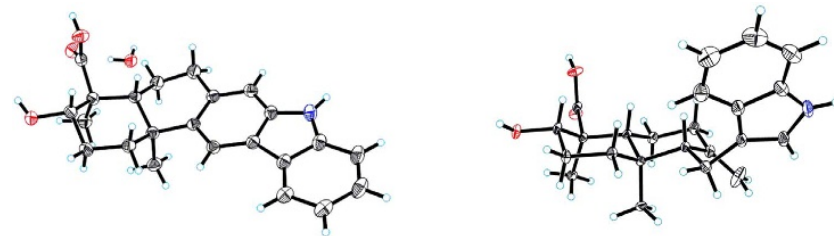

ORTEP of 1

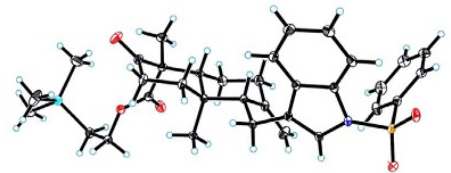

ORTEP of 40

Figure 4 | ORTEP drawings of compounds 1, 6 and 40. Non-hydrogen atoms are shown as 30\% ellipsoids. The stereochemical outcomes of the radical cyclization cascades are unambiguously confirmed. 
$\mathrm{RO}_{2} \mathrm{C}$

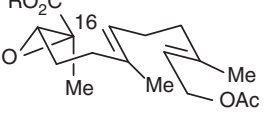

'CP $\mathrm{P}_{2} \mathrm{Ti}(\mathrm{III}) \mathrm{Cl}$

12

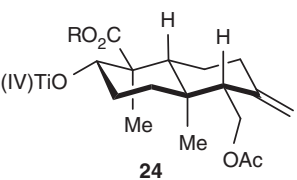

' $\mathrm{Cp}_{2} \mathrm{Ti}(\mathrm{III}) \mathrm{Cl}$
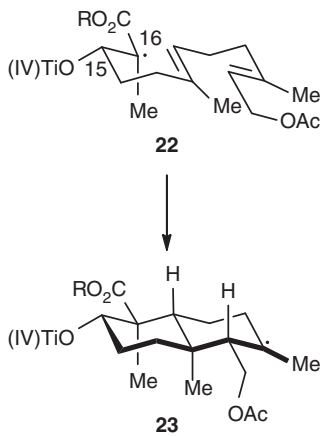

Figure 5 | A postulated mechanism of the Ti(III)-mediated radical

cyclization. The epoxy ester serves as a suitable substrate for this reaction. The trans-decalin system with an equatorial alkoxycarbonyl and an exocyclic methylene groups is obtained.

cyclization, such as the preference to the formation of products with tri-/tetrasubstituted olefins and difficulty generating carbocations with electron-withdrawing substituents, this radical chemistry offers a useful and complementary route for preparing functionalized sesquiterpenoid synthons.

We then focused on the synthesis of oridamycin A bearing an axial carboxylic substituent on $\mathrm{C} 16$ (Fig. 6). The cis-epoxy analogue of $\mathbf{1 2}$ was first prepared and subjected to the $\mathrm{Ti}$ (III) conditions. However, the compound $\mathbf{1 3}$ with an equatorial carboxylic substituent was detected as the major product, presumably due to the fast rotation of the $\mathrm{C} 15-\mathrm{C} 16$ bond to adopt the sterically favoured conformation (Fig. 5) for the cyclization. Thus, we made recourse to a mechanistically different oxidative radical cyclization mediated by $\mathrm{Mn}(\mathrm{III})^{55-59}$ using $\beta$ ketoester 25 (ref. 56) as a substrate. Treatment with $\mathrm{Mn}(\mathrm{OAc})_{3} /$ $\mathrm{Cu}(\mathrm{OAc})_{2}$ in DMSO effected the radical cyclization with an acceptable yield of decalin 26 (48\%, a single diastereomer<smiles>CCOC(C)C(=O)CC/C(C)=C/CC/C(C)=C/COC(C)=O</smiles>

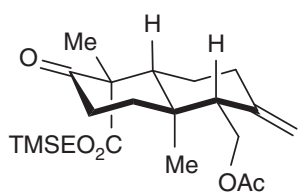

26
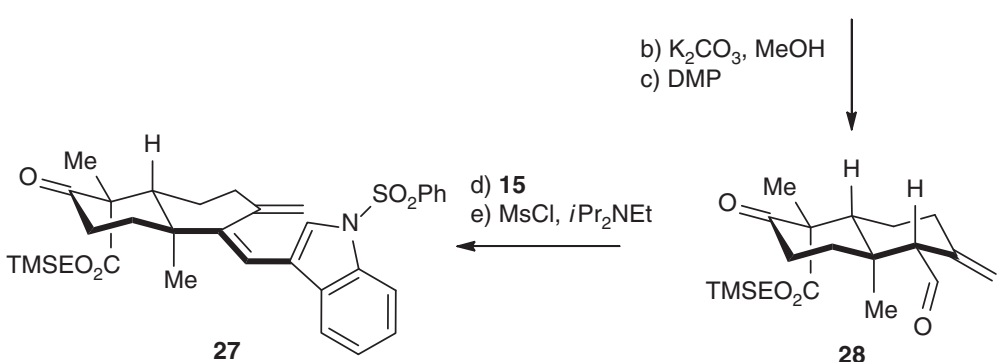

28

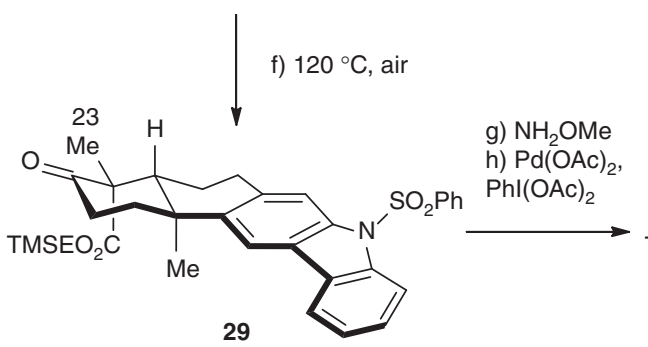

29

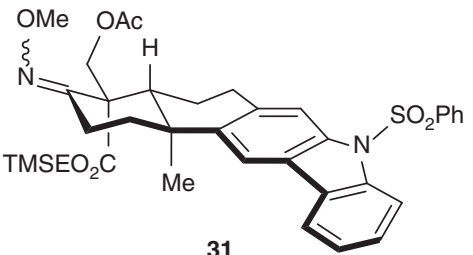

31

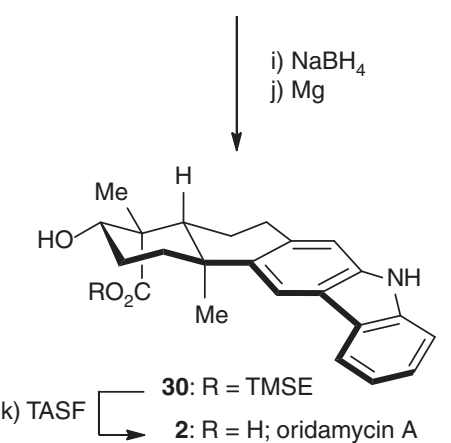

m) $\mathrm{NaBH}_{4}$

n) $\mathrm{Mg}$

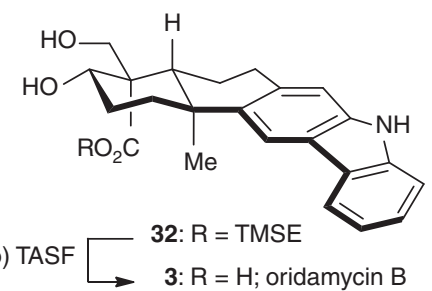

l) $\mathrm{HClO}_{4}$

Figure 6 | The $\mathbf{6} \pi$-electrocyclization/aromatization approach towards the total syntheses of oridamycins $\mathbf{A}$ and $\mathbf{B}$. Reagents and conditions:

(a) $\mathrm{Mn}(\mathrm{OAc})_{3} \bullet 2 \mathrm{H}_{2} \mathrm{O}(2.0 \mathrm{eq}), \mathrm{Cu}(\mathrm{OAc})_{2} \bullet \mathrm{H}_{2} \mathrm{O}(1.0 \mathrm{eq}), \mathrm{DMSO}, 22^{\circ} \mathrm{C}, 12 \mathrm{~h}, 48 \%$; (b) $\mathrm{K}_{2} \mathrm{CO}_{3}(1.5 \mathrm{eq}), \mathrm{MeOH}, 22^{\circ} \mathrm{C}, 3 \mathrm{~h}$; (c) DMP (2.0 eq), $\mathrm{CH}_{2} \mathrm{Cl}_{2}, 22^{\circ} \mathrm{C}$, $30 \mathrm{~min}, 92 \%$ (two steps); (d) 15 (3.0 eq), THF, $22^{\circ} \mathrm{C}, 40 \mathrm{~min}$; (e) $\mathrm{MsCl}(1.2 \mathrm{eq}), i \operatorname{Pr}{ }_{2} \mathrm{NEt}(1.5 \mathrm{eq}), \mathrm{CH}_{2} \mathrm{Cl}_{2}, 0^{\circ} \mathrm{C}, 1 \mathrm{~h}, 74 \%$ ( 2 steps); (f) air, DMSO, $120^{\circ} \mathrm{C}, 2 \mathrm{~h}$, 83\%; (g) $\mathrm{NH}_{2} \mathrm{OMe} \bullet \mathrm{HCl}\left(2.0 \mathrm{eq}\right.$ ), pyridine, $22^{\circ} \mathrm{C}, 2 \mathrm{~h}, 94 \%$; (h) $\mathrm{Pd}(\mathrm{OAc})_{2}(20 \mathrm{~mol} \%), \mathrm{Phl}(\mathrm{OAc})_{2}(1.0 \mathrm{eq}), \mathrm{Ac}_{2} \mathrm{O} / \mathrm{AcOH}^{\circ}(1), 110^{\circ} \mathrm{C}, 1 \mathrm{~h}, 82 \%$; (i) $\mathrm{NaBH} 4$ (3.0 eq), $\mathrm{MeOH}, 0{ }^{\circ} \mathrm{C}, 30 \mathrm{~min} ;(\mathrm{j}) \mathrm{Mg}(8.0 \mathrm{eq}), \mathrm{MeOH}, 22^{\circ} \mathrm{C}, 1 \mathrm{~h}, 83 \%$ (two steps); (k) TASF $(2.0 \mathrm{eq}), \mathrm{DMF}, 50{ }^{\circ} \mathrm{C}, 92 \% ;(\mathrm{I})$ aq. $\mathrm{HClO}{ }_{4}(6.0 \mathrm{M}) / \mathrm{acetone}$ (1:3), $22^{\circ} \mathrm{C}, 12 \mathrm{~h} ;(\mathrm{m}) \mathrm{NaBH}_{4}$ (3.0 eq), $\mathrm{MeOH}, 0{ }^{\circ} \mathrm{C}, 30 \mathrm{~min}, 62 \%$ (2 steps); (n) $\mathrm{Mg}(8.0 \mathrm{eq}), \mathrm{MeOH}, 22^{\circ} \mathrm{C}, 1 \mathrm{~h}, 90 \%$; (o) TASF (2.0 eq), DMF, $50{ }^{\circ} \mathrm{C}, 91 \%$. 
detected). This compound was subjected to a sequence similar to that described above to afford triene 27 with good overall efficiency, via the intermediacy of aldehyde 28. Under thermal conditions $\left(120^{\circ} \mathrm{C}\right)$ and in presence of air, 27 was converted to carbazole 29 ( $83 \%$ yield) in one pot. Sequential ketone reduction $\left(\mathrm{NaBH}_{4}\right)$ and desulfonylation $(\mathrm{Mg} / \mathrm{MeOH})$ provided compound 30 in $83 \%$ overall yield. Final TMSE deprotection led to the completion of the first synthesis of ( \pm )-oridamycin A (2).

We accomplished the synthesis of oridamycin B for the first time by adjusting the C23 oxidation state of 29 (Fig. 6), taking advantage of the neighbouring ketone carbonyl group. $O$-Methyloxime formation afforded the substrate suitable for a directed $\mathrm{C}-\mathrm{H}$ bond oxidation, and Sanford's conditions $\left[\mathrm{Pd}(\mathrm{OAc})_{2}(20 \mathrm{~mol} \%), \mathrm{PhI}(\mathrm{OAc})_{2}\right]^{60,61}$ were effective to give the desired acetate $\mathbf{3 1}$ with good overall efficiency. It should be noted that stoichiometric Pd-mediated $\mathrm{Csp}^{3}-\mathrm{H}$ bond oxidation reactions have been exploited in terpenoid synthesis ${ }^{41,62,63}$. Deprotection of the oxime and acetate, followed by reduction and desulfonylation, afforded diol 32 with acceptable overall efficiency. Removal of TMSE with TASF provided ( \pm )-oridamycin B (3) in $91 \%$ yield. The spectroscopic data of the synthetic samples of oridamycins A and B matched those reported for the natural products.

The $\mathrm{C}-\mathrm{H}$ bond activation/Heck annulation approach. The second approach to xiamycin A (1) fulfilled the strategy of indole $\mathrm{C} 2-\mathrm{H}$ activation/Heck-type annulation (Fig. 7). Stille coupling ${ }^{64}$ of 12 with $N$-Boc-3-(tributylstannyl)indole $33^{65}$ followed by deprotection of Boc $^{66}$ provided a fully functionalized precursor 34 (66\% overall yield), which underwent a Ti(III)-catalysed radical cyclization under the same conditions as above to give decalin 35 as a single diastereomer in $60 \%$ yield $^{39}$. In the presence of $\mathrm{Pd}(\mathrm{OAc})_{2}$ and $p$-benzoquinone at $50^{\circ} \mathrm{C}$ (refs 28,29), 35 was converted to carbazole 21 in $81 \%$ yield, presumably through the devised oxidative Heck/aromatization sequence. TMSE deprotection of $\mathbf{3 5}$ and $\mathbf{2 1}$ with TASF then afforded
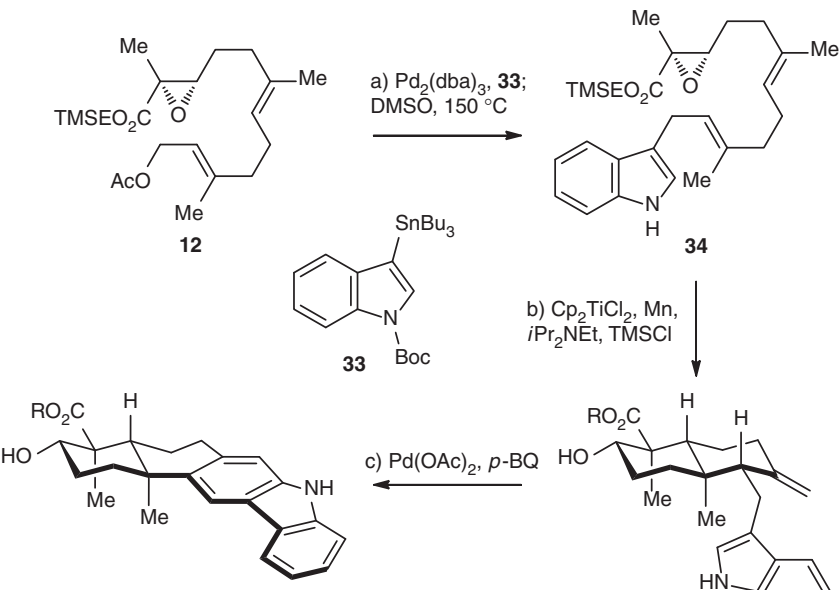

$$
\begin{aligned}
\text { d) TASF } \longrightarrow \text { 21: } \mathrm{R}=\text { TMSE } \\
\longrightarrow \text { 1: } \mathrm{R}=\mathrm{H} \text {; xiamycin } \mathrm{A}
\end{aligned}
$$$$
\text { d) TASF } \longrightarrow \text { 35: R }=\text { TMSE }
$$
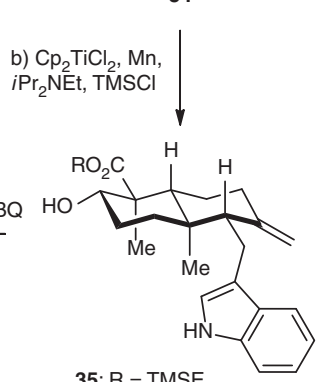

Figure 7 | The oxidative Heck annulation approach towards the total synthesis of xiamycin A. Reagents and conditions: (a) $\mathrm{Pd}_{2}(\mathrm{dba})_{3}(5 \mathrm{~mol} \%)$, $\mathrm{LiCl}$ (3.0 eq), 33 (2.0 eq), DMF, $80^{\circ} \mathrm{C}, 2 \mathrm{~h}$, then DMSO, $150^{\circ} \mathrm{C}, 30 \mathrm{~min}$, $66 \%$; (b) $\mathrm{Cp}_{2} \mathrm{TiCl}_{2}$ (20 mol\%), Mn (8.0 eq), iPr $\operatorname{Pr}_{2} \mathrm{NEt}$ (6.0 eq), $\mathrm{TMSCl}$ (5.0 eq), $\mathrm{THF}, 22^{\circ} \mathrm{C}, 4 \mathrm{~h}, 60 \%$; (c) $\mathrm{Pd}(\mathrm{OAc})_{2}(20 \mathrm{~mol} \%), \mathrm{p}$-benzoquinone (2.0 eq), $\mathrm{AcOH}$ /toluene $(1: 4), 50^{\circ} \mathrm{C}, 2 \mathrm{~h}, 81 \%$; (d) $\operatorname{TASF}(2.0 \mathrm{eq}), \mathrm{DMF}, 50^{\circ} \mathrm{C}$, $95 \%$ for $\mathbf{1}, 91 \%$ for 6 .

indosespene (6) and xiamycin A (1), respectively. The structure of 6 was verified by X-ray crystallographic analysis (Fig. 4).

The above strategy was further applied to alternative syntheses of oridamycins A and B (Fig. 8). In this case, an indole-containing $\beta$-ketoester 36 was employed as the substrate for the $\mathrm{Mn}$ (III) mediated cyclization. $N$-Sulfonylation of 3-geranylindole 37 (ref. 67; $\mathrm{NaOH}, \mathrm{PhSO}_{2} \mathrm{Cl}$ ) and subsequent allylic oxidation $\left(\mathrm{SeO}_{2}, t \mathrm{BuOOH}\right)$ gave alcohol 38 in $78 \%$ overall yield, which underwent bromination $\left(\mathrm{Et}_{3} \mathrm{~N}, \mathrm{MsCl}\right.$; $\left.\mathrm{LiBr}\right)$ followed by

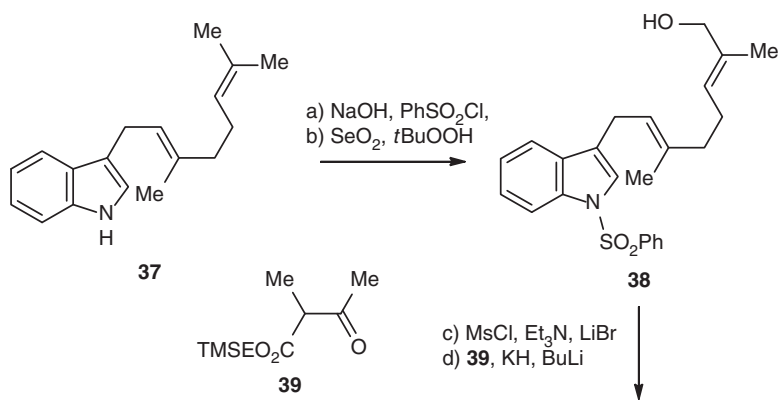

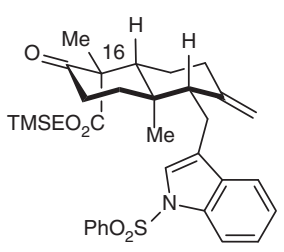

40
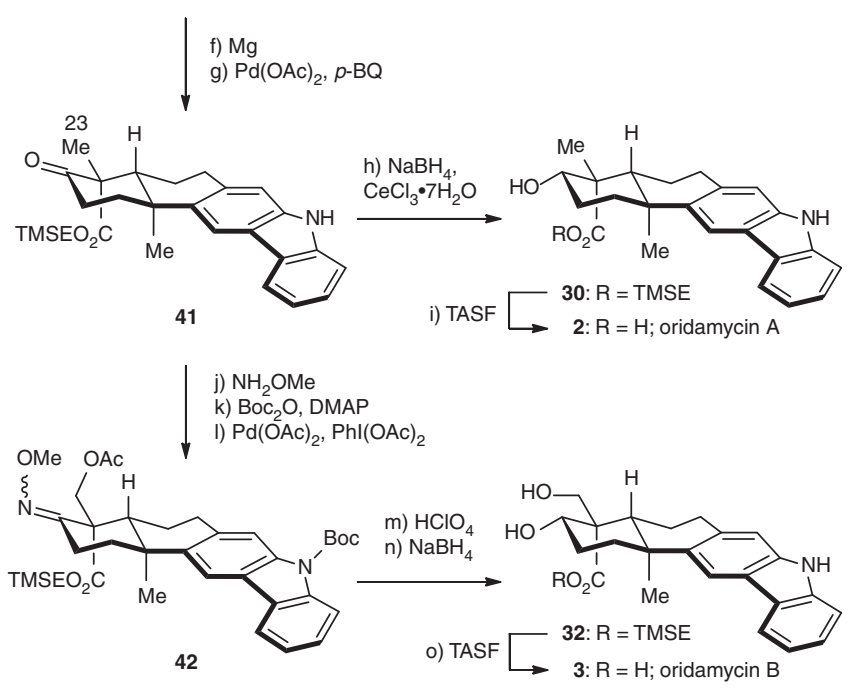

Figure 8 | The oxidative Heck annulation approach towards the total syntheses of oridamycins $\mathbf{A}$ and $\mathbf{B}$. Reagents and conditions: (a) $\mathrm{PhSO}_{2} \mathrm{Cl}$ (2.0 eq), $\mathrm{Bu}_{4} \mathrm{NBr}(10 \mathrm{~mol} \%)$, aq. $\mathrm{NaOH}(50 \mathrm{wt} \%) /$ toluene $(1: 2), 22^{\circ} \mathrm{C}, 3 \mathrm{~h}$; (b) $\mathrm{SeO}_{2}(20 \mathrm{~mol} \%), \mathrm{tBuOOH}(2.0 \mathrm{eq}), \mathrm{CH}_{2} \mathrm{Cl}_{2}, 0^{\circ} \mathrm{C}, 10 \mathrm{~h}, 78 \%$ (two steps); (c) $\mathrm{Et}_{3} \mathrm{~N}$ (1.5 eq), $\mathrm{MsCl}(1.2 \mathrm{eq}), \mathrm{LiBr}(5.0 \mathrm{eq}), \mathrm{THF}^{\circ} \mathrm{O}^{\circ} \mathrm{C}, 30 \mathrm{~min}$; (d) 39, (1.0 eq), $\mathrm{KH}(1.2 \mathrm{eq}), \mathrm{BuLi}(1.2 \mathrm{eq}), \mathrm{THF} / \mathrm{HMPA}(5: 1), 0^{\circ} \mathrm{C}, 3 \mathrm{~h}, 80 \%$ (two steps); (e) $\mathrm{Mn}(\mathrm{OAc})_{3} \bullet 2 \mathrm{H}_{2} \mathrm{O}$ (2.0 eq), $\mathrm{Cu}(\mathrm{OAc})_{2} \bullet \mathrm{H}_{2} \mathrm{O}(1.0 \mathrm{eq}$ ), DMSO, $22^{\circ} \mathrm{C}, 12 \mathrm{~h}, 52 \%$; (f) $\mathrm{Mg}$ (3.0 eq), $\mathrm{NH}_{4} \mathrm{Cl}(1.2 \mathrm{eq}), \mathrm{MeOH}, 22^{\circ} \mathrm{C}, 1 \mathrm{~h}$, 96\%; (g) $\mathrm{Pd}(\mathrm{OAc})_{2}$ (20 mol\%), p-benzoquinone (2.5 eq), $\mathrm{AcOH} /$ toluene (1:4), $50{ }^{\circ} \mathrm{C}, 2 \mathrm{~h}, 65 \%$; (h) $\mathrm{NaBH}_{4}$ (3.0 eq), $\mathrm{CeCl}_{3} \bullet 7 \mathrm{H}_{2} \mathrm{O}$ (3.0 eq), $\mathrm{MeOH}$, $0^{\circ} \mathrm{C}, 30 \mathrm{~min}$; (i) TASF (2.0 eq), DMF, $50{ }^{\circ} \mathrm{C}, 2 \mathrm{~h}, 85 \%$ (two steps); (j) $\mathrm{NH}_{2} \mathrm{OMe} \bullet \mathrm{HCl}(2.0 \mathrm{eq})$, pyridine, $22{ }^{\circ} \mathrm{C}, 2 \mathrm{~h}, 93 \%$; (k) $\mathrm{Boc}_{2} \mathrm{O}(2.0 \mathrm{eq})$, 4-DMAP (2.0 eq), THF, $22^{\circ} \mathrm{C}, 1 \mathrm{~h}, 89 \%$; (I) $\mathrm{Pd}(\mathrm{OAc})_{2}$ (20 mol\%), $\mathrm{Phl}(\mathrm{OAc})_{2}(1.1 \mathrm{eq}), \mathrm{Ac}_{2} \mathrm{O} / \mathrm{AcOH}(1: 1), 110^{\circ} \mathrm{C}, 1 \mathrm{~h}, 81 \% ;(\mathrm{m})$ aq. $\mathrm{HClO}_{4}(6.0$ $\mathrm{M}) /$ acetone (1:3), $22^{\circ} \mathrm{C}, 8 \mathrm{~h}$; (n) $\mathrm{NaBH}_{4}(3.0 \mathrm{eq}), \mathrm{MeOH}, 0^{\circ} \mathrm{C}, 30 \mathrm{~min}$, $54 \%$ (two steps); (o) $\operatorname{TASF}(2.0 \mathrm{eq}), \mathrm{DMF}, 50^{\circ} \mathrm{C}, 2 \mathrm{~h}, 91 \%$. 


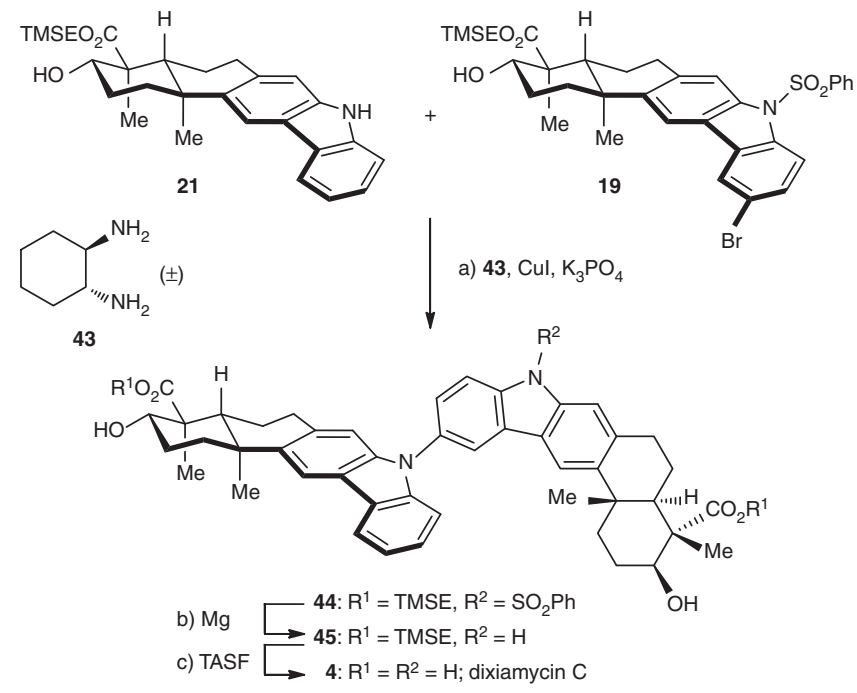

Figure $\mathbf{9}$ | Total synthesis of dixiamycin C. Reagents and conditions: (a) Cul (1.5 eq), 21 (1.0 eq), 19 (1.5 eq), ( \pm ) -43 (3.0 eq), $\mathrm{K}_{3} \mathrm{PO}_{4}$ (7.5 eq), 1,4dioxane, $110{ }^{\circ} \mathrm{C}, 12 \mathrm{~h}$; (b) $\mathrm{Mg}(6.0 \mathrm{eq}), \mathrm{MeOH}, 22^{\circ} \mathrm{C}, 1 \mathrm{~h}, 51 \%$ for the two steps; (c) TASF (4.0 eq), DMF, $50^{\circ} \mathrm{C}, 5 \mathrm{~h}, 96 \%$.

alkylation with the dianion generated from $\beta$-ketoester $39(\mathrm{KH}$, then $\mathrm{BuLi}$ ) to furnish 36 ( $80 \%$ yield for the two steps). Under the similar conditions used for the cyclization of compound 25 (Fig. 6), decalin 40 was obtained in 52\% yield as a single detectable diastereomer. Its $\mathrm{C} 16$ stereochemistry was secured by $\mathrm{X}$-ray crystallographic analysis (Fig. 4). Desulfonylation (Mg/ $\mathrm{MeOH}, 96 \%$ yield) and subsequent oxidative Heck annulation (vide supra) afforded carbazole 41 (65\% yield), which was subjected to a two-step sequence of ketone reduction and TMSE deprotection to give $( \pm)$-oridamycin A (2). Sanford $\mathrm{Csp}^{3}-\mathrm{H}$ bond oxidation was exploited again for the synthesis of oridamycin B from 41; deactivation of the carbazole motif with an electron-withdrawing $N$-protecting group was required. Thus, 41 was subjected to $\mathrm{NH}_{2} \mathrm{OMe}$ condensation and $\mathrm{Boc}$ protection to afford the oxidation precursor. The same conditions $\left[\mathrm{Pd}(\mathrm{OAc})_{2}(20 \mathrm{~mol} \%), \mathrm{PhI}(\mathrm{OAc})_{2}\right]$ as used before delivered acetate 42 smoothly (67\% yield for the three steps). Global deprotection of the oxime, acetyl and Boc groups under acidic conditions followed by reduction of the exposed carbonyl group furnished the late intermediate 32 in $54 \%$ overall yield, which was converted to $( \pm)$-oridamycin B (3) through the removal of TMSE group.

The synthesis of dixiamycin C. Having synthesized the monomeric natural products, we directed our attention to the synthesis of dixiamycin C (Fig. 9). Starting from coupling partners 19 and 21, we investigated a variety of conditions for the transition metal promoted $\mathrm{C}-\mathrm{N}$ bond formation. Buchwald's protocol ${ }^{68}$ [CuI, ( \pm ) $-43, \mathrm{~K}_{3} \mathrm{PO}_{4}, 110^{\circ} \mathrm{C}$ ] proved to be optimal to provide dimer 44. Deprotection of the benzenesulfonyl and TMSE groups furnished dixiamycin $C$ (4) in a good overall yield, via the intermediacy of 45. The spectra and physical properties of the synthetic dixiamycin $\mathrm{C}$ were consistent with those reported for the natural products.

The antiviral activity. The activities of synthetic xiamycin A (1), oridamycins A (2), dixiamycin C (4), indosespene (6) and sespenine ${ }^{14,16}$ against HSV-1 and hepatitis $\mathrm{C}$ virus (HCV) were evaluated. Notably, xiamycin A was reported to possess moderate anti-HIV activity but no significant cytotoxicity against a number of human tumour cell lines ${ }^{16}$, and a structurally relevant

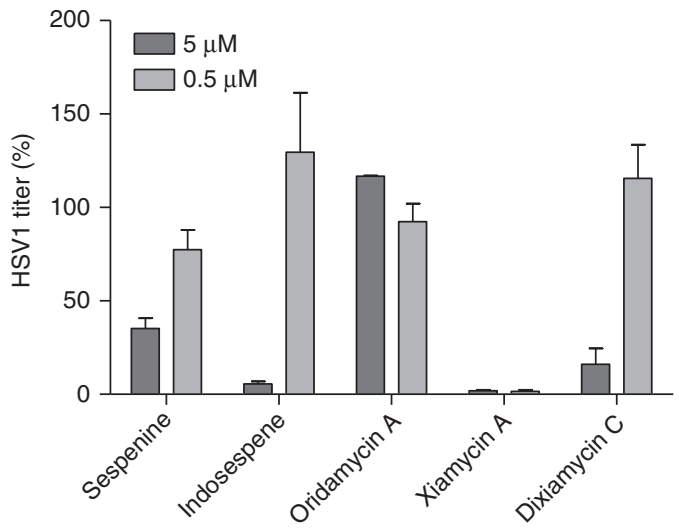

Figure 10 | Effects of the synthetic compounds on HSV-1 propagation. Vero cells were infected with HSV1 (strain KOS-ATCC VR1493) for $3 \mathrm{~h}$ and then treated with different concentrations of compounds for $20 \mathrm{~h}$. HSV-1 in the culture supernatants were then quantified by using $T_{C I D}$ assay. Virus titres were presented as the percentages of the mock DMSO treatment. Data represent means \pm s.e.m. of six individual infections.

carbazole natural product, named tubingensin $\mathrm{A}$, was found to exhibit anti-HSV-1 activity (without details disclosed) ${ }^{69}$. We treated HSV-1 (KOS strain)-infected vero cells with 5.0 and $0.50 \mu \mathrm{M}$ solutions of the compounds for $20 \mathrm{~h}$ and then quantified the infectious HSV-1 titres in the supernatants by using TCID $_{50}$ assay $^{70}$. As shown in Fig. 10, 1, 4, 6 and sespenine can suppress HSV-1 propagation in a dose-dependent manner. Notably, xiamycin $\mathrm{A}(\mathbf{1})$ is the most potent compound that reduces $>95 \%$ of virus propagation at a concentration of $0.50 \mu \mathrm{M}$. Indosespene (6) significantly inhibits $\mathrm{HSV}-1$ propagation at the concentration of $5.0 \mu \mathrm{M}$ and displays essentially no antiviral activity at the concentration of $0.50 \mu \mathrm{M}$. Dixiamycin C (4) and sespenine show moderate inhibitory activity against HSV-1 at $5.0 \mu \mathrm{M}$ but no activity at $0.50 \mu \mathrm{M}$. For the anti-HCV test (using a replicon assay), only dixiamycin $C$ (6) exhibited inhibitory activity at a high concentration $(50 \mu \mathrm{M}$, see Supplementary Fig. 81). It should be mentioned that these compounds did not exhibit cytotoxicity against the cells used for both anti-HSV-1 and HCV tests (see Supplementary Fig. 82).

\section{Discussion}

We have accomplished the total synthesis of indolosesquiterpenoids xiamycin $\mathrm{A}$, oridamycins $\mathrm{A}$ and $\mathrm{B}$, dixiamycin $\mathrm{C}$ and indosespene. Two unified strategies for the framework construction and a series of transition-metal-mediated reactions formed the basis of the synthesis. Antiviral tests of the synthetic natural products revealed that xiamycin A exhibits a potent inhibitory activity against HSV-1.

\section{Methods}

General. All reactions were carried out under an argon atmosphere with dry solvents under anhydrous conditions, unless otherwise noted. Tetrahydrofuran (THF), toluene and 1,4-dioxane were distilled immediately before use from sodium-benzophenone ketyl. Methylene chloride $\left(\mathrm{CH}_{2} \mathrm{Cl}_{2}\right), \mathrm{N}, \mathrm{N}$-dimethylformamide (DMF), dimethyl sulfoxide (DMSO), hexamethylphosphoramide (HMPA), triethylamine $\left(\mathrm{Et}_{3} \mathrm{~N}\right), \mathrm{N}, \mathrm{N}$-diisopropylethylamine $\left(i \mathrm{Pr}_{2} \mathrm{NEt}\right)$ and pyridine were distilled from calcium hydride and stored under an argon atmosphere. Methanol $(\mathrm{MeOH})$ was distilled from magnesium and stored under an argon atmosphere. Acetone was dried over drierite and distilled before use. Reagents were purchased at the highest commercial quality and used without further purification, unless otherwise stated. Solvents for chromatography were used as supplied by Titan Chemical. Reactions were monitored by thin layer chromatography (TLC) carried out on S-2 $0.25 \mathrm{~mm}$ E. Merck silica gel plates (60F-254) using UV light as a visualizing agent and aqueous ammonium cerium nitrate/ammonium molybdate or basic aqueous potassium permanganate as a developing agent. E. Merck silica gel 
(60, particle size $0.040-0.063 \mathrm{~mm}$ ) was used for flash column chromatography. Preparative thin layer chromatography separations were carried out on 0.25 or $0.50 \mathrm{~mm}$ E. Merck silica gel plates (60F-254). NMR spectra were recorded on Bruker AV-400, DRX-600 or Agilent 500/54/ASP instrument and calibrated by using residual undeuterated chloroform $\left(\delta_{\mathrm{H}}=7.26\right.$ p.p.m. $)$ and $\mathrm{CDCl}_{3}$

$\left(\delta_{\mathrm{C}}=77.16\right.$ p.p.m. $)$, or undeuterated methanol $\left(\delta_{\mathrm{H}}=3.31\right.$ p.p.m. $)$ and methanol- $\mathrm{d}_{4}$ $\left(\delta_{\mathrm{C}}=49.00\right.$ p.p.m.), as internal references. IR spectra were recorded on a Thermo Scientific Nicolet 380 FT-IR spectrometer. Melting points (m.p.) are uncorrected and were recorded on a SGW X-4 apparatus. High-resolution mass spectra (HRMS) were recorded on a Bruker APEXIII 7.0 Tesla ESI-FT mass spectrometer.

For ${ }^{1} \mathrm{H}$ and ${ }^{13} \mathrm{C}$ NMR spectra of compounds, see Supplementary Figs 1-70. For the comparisons of ${ }^{1} \mathrm{H}$ and ${ }^{13} \mathrm{C}$ NMR spectra of the natural and synthetic natural products, see Supplementary Figs $71-80$. For the comparisons of ${ }^{1} \mathrm{H}$ and ${ }^{13} \mathrm{C}$ NMR spectroscopic data of the natural and synthetic natural products, see Supplementary Tables 1-10. For the experimental procedures, and spectroscopic and physical data of compounds, the antiviral assay and cytotoxicity assays, and the crystallographic data of compounds $\mathbf{1 , 6}$ and $\mathbf{4 0}$, see Supplementary Methods.

\section{References}

1. O'Connor, S. E. \& McCoy, E. Terpene Indole Alkaloid Biosynthesis in Recent Advances in Phytochemistry Vol. 40 (ed. Romeo, J. T.) 1-22 (Elsevier, 2006)

2. Marcos, I. S., Moro, R. F., Costales, I., Basabe, P. \& Díez, D. Sesquiterpenyl indoles. Nat. Prod. Rep. 30, 1509-1526 (2013).

3. Lacey, E., Power, M., Wu, Z. \& Rickards, R. W. Terpenylated Diketopiperazines, (Drimentines). WO 1998/009968, March 12, 1998.

4. Uchida, R., Kim, Y. P., Namatame, I, Tomoda, H. \& Ōmura, S. Sespendole, a new inhibitor of lipid droplet synthesis in macrophages, produced by Pseudobotrytis terrestris FKA-25. J. Antibiot. 59, 93-97 (2006).

5. Roll, D. M. et al. The lecanindoles, nonsteroidal progestins from the terrestrial fungus Verticillium lecanii 6144. J. Nat. Prod. 72, 1944-1948 (2009).

6. Che, Q. et al. Hybrid isoprenoids from a reeds rhizosphere soil derived actinomycete Streptomyces sp. CHQ-64. Org. Lett. 14, 3438-3441 (2012).

7. Che, Q. et al. Polycyclic hybrid isoprenoids from a reed rhizosphere soil derived Streptomyces sp. CHQ-64. J. Nat. Prod. 76, 759-763 (2013).

8. Velthuisen, E. J. \& Danishefsky, S. J. Total synthesis of (+)-suaveolindole: establishment of its absolute configuration. J. Am. Chem. Soc. 129, 10640-10641 (2007)

9. Marcos, I. S. et al. Synthesis of 12-epi-ent-polyalthenol an antitumour indole sesquiterpene alkaloid. Tetrahedron 68, 7932-7940 (2012).

10. Marcos, I. S. et al. Biomimetic synthesis of an antitumour indole sesquiterpene alkaloid, 12-epi-ent-pentacyclindole. Tetrahedron 69, 7285-7289 (2013).

11. Asanuma, A., Enomoto, M., Nagasawa, T. \& Kuwahara, S. Synthesis of ( \pm )-lecanindole D. Tetrahedron Lett. 54, 4561-4563 (2013).

12. Sun, Y., Li, R., Zhang, W. \& Li, A. Total synthesis of indotertine A and drimentines A, F, and G. Angew. Chem. Int. Ed. 52, 9201-9204 (2013).

13. Rosen, B. R., Werner, E. W., O'Brien, A. G. \& Baran, P. S. Total synthesis of dixiamycin B by electrochemical oxidation. J. Am. Chem. Soc. 136, 5571-5574 (2014).

14. Sun, Y. et al. Bioinspired total synthesis of sespenine. Angew. Chem. Int. Ed. 53, 9012-9016 (2014)

15. Ding, L. et al. Xiamycin, a pentacyclic indolosesquiterpene with selective antiHIV activity from a bacterial mangrove endophyte. Bioorg. Med. Chem. Lett. 20, 6685-6687 (2010).

16. Ding, L., Maier, A., Fiebig, H. H., Lin, W. H. \& Hertweck, C. A family of multicyclic indolosesquiterpenes from a bacterial endophyte. Org. Biomol. Chem. 9, 4029-4031 (2011).

17. Xu, Z., Baunach, M., Ding, L. \& Hertweck, C. Bacterial synthesis of diverse indole terpene alkaloids by an unparalleled cyclization sequence. Angew. Chem. Int. Ed. 51, 10293-10297 (2012)

18. Baunach, M., Ding, L., Bruhn, T., Bringmann, G. \& Hertweck, C. Regiodivergent $\mathrm{N}-\mathrm{C}$ and $\mathrm{N}-\mathrm{N}$ aryl coupling reactions of indoloterpenes and cycloether formation mediated by a single bacterial flavoenzyme. Angew. Chem. Int. Ed. 52, 9040-9043 (2013).

19. Li, H. et al. Identification and characterization of xiamycin A and oxiamycin gene cluster reveals an oxidative cyclization strategy tailoring indolosesquiterpene biosynthesis. J. Am. Chem. Soc. 134, 8996-9005 (2012).

20. Zhang, Q. et al. Carboxyl formation from methyl via triple hydroxylations by xiaM in xiamycin A biosynthesis. Org. Lett. 14, 6142-6145 (2012).

21. Zhang, Q. et al. N-N-Coupled indolo-sesquiterpene atropo-diastereomers from a marine-derived actinomycete. Eur. J. Org. Chem. 27, 5256-5262 (2012).

22. Takada, K., Kajiwara, H. \& Imamura, N. Oridamycins A and B, antisaprolegnia parasitica indolosesquiterpenes isolated from Streptomyces sp. KS84. J. Nat. Prod. 73, 698-701 (2010).

23. Beaudry, C. M., Malerich, J. P. \& Trauner, D. Biosynthetic and biomimetic electrocyclizations. Chem. Rev. 105, 4757-4778 (2005).

24. Ferreira, E. M., Zhang, H. \& Stoltz, B. M. Oxidative Heck-Type Reactions (Fujiwara-Moritani Reactions), in The Mizoroki-Heck Reaction (ed. Oestreich, M.) 345-382 (John Wiley \& Sons, 2009).
25. Baran, P. S. \& Corey, E. J. A short synthetic route to $(+)$-austamide, $(+)$-deoxyisoaustamide, and $(+)$-hydratoaustamide from a common precursor by a novel palladium-mediated indole $\rightarrow$ dihydroindoloazocine cyclization. J. Am. Chem. Soc. 124, 7904-7905 (2002).

26. Ferreira, E. M. \& Stoltz, B. M. Catalytic C-H bond functionalization with palladium(II): aerobic oxidative annulations of indoles. J. Am. Chem. Soc. 125 9578-9579 (2003).

27. Grimster, N. P., Gauntlett, C., Godfrey, C. R. A. \& Gaunt, M. J. Palladiumcatalyzed intermolecular alkenylation of indoles by solvent-controlled regioselective C-H functionalization. Angew. Chem. Int. Ed. 44, 3125-3129 (2005).

28. Kong, A., Han, X. \& Lu, X. Highly efficient construction of benzene ring in carbazoles by palladium-catalyzed endo-mode oxidative cyclization of 3-(3'-alkenyl)indoles. Org. Lett. 8, 1339-1342 (2006).

29. Han, X. \& Lu, X. Novel Palladium-catalyzed acyloxylation/cyclization of 2-(3'-alkenyl)indoles. Org. Lett. 11, 2381-2384 (2009).

30. Bian, M. et al. Total syntheses of anominine and tubingensin A. J. Am. Chem. Soc 134, 8078-8081 (2012).

31. Lu, Z., Li, Y., Deng, J. \& Li, A. Total synthesis of the Daphniphyllum alkaloid daphenylline. Nat. Chem. 5, 679-684 (2013).

32. Nugent, W. A. \& RajanBabu, T. V. Transition-metal-centered radicals in organic synthesis. Titanium(III)-induced cyclization of epoxy olefins. J. Am. Chem. Soc. 110, 8561-8562 (1988).

33. RajanBabu, T. V. \& Nugent, W. A. Selective generation of free radicals from epoxides using a transition-metal radical. A powerful new tool for organic synthesis. J. Am. Chem. Soc. 116, 986-997 (1994).

34. Gansäuer, A., Pierobon, M. \& Bluhm, H. Catalytic, Highly regio- and chemoselective generation of radicals from epoxides: titanocene dichloride as an electron transfer catalyst in transition metal catalyzed radical reactions. Angew. Chem. Int. Ed. 37, 101-103 (1998).

35. Gansäuer, A., Bluhm, H. \& Pierobon, M. Emergence of a novel catalytic radical reaction: Titanocene-catalyzed reductive opening of epoxides. J. Am. Chem. Soc. 120, 12849-12859 (1998).

36. Fernández-Mateos, A., Martin de la Nava, E., Pascual Coca, G., Ramos Silva, A. \& Rubio González, R. Radicals from epoxides. Intramolecular addition to aldehyde and ketone carbonyls. Org. Lett. 1, 607-610 (1999).

37. Barrero, A. F., Cuerva, J. M., Herrador, M. M. \& Valdivia, M. V. A new strategy for the synthesis of cyclic terpenoids based on the radical opening of acyclic epoxypolyenes. J. Org. Chem. 66, 4074-4078 (2001).

38. Justicia, J. et al. Titanocene-catalyzed cascade cyclization of epoxypolyprenes: straightforward synthesis of terpenoids by free-radical chemistry. Chem. Eur. J. 10, 1778-1788 (2004).

39. Justicia, J., Oltra, J. E. \& Cuerva, J. M. General approach to polycyclic meroterpenoids based on Stille couplings and titanocene catalysis. J. Org. Chem. 69, 5803-5806 (2004).

40. Justicia, J. et al. 7-endo Radical cyclizations catalyzed by Titanocene(III). Straightforward synthesis of terpenoids with seven-membered carbocycles. J. Am. Chem. Soc. 127, 14911-14921 (2005).

41. Justicia, J., Oltra, J. E. \& Cuerva, J. M. Exploiting $\mathrm{Pd}^{\mathrm{II}}$ and $\mathrm{Ti}^{\mathrm{III}}$ chemistry to obtain $\gamma$-dioxygenated terpenoids: synthesis of rostratone and novel approaches to aphidicolin and pyripyropene A. J. Org. Chem. 70, 8265-8272 (2005).

42. Gansäuer, A. \& Narayan, S. Titanocene-catalysed electron transfer-mediated opening of epoxides. Adv. Synth. Catal. 344, 465-475 (2002).

43. Barrero, A. F., Quílez del Moral, J. F., Sánchez, E. M. \& Arteaga, J. F. Titanocene-mediated radical cyclization: an emergent method towards the synthesis of natural products. Eur. J. Org. Chem. 7, 1627-1641 (2006).

44. Cuerva, J. M., Justicia, J., Oller-López, J. L. \& Oltra, J. E. C $\mathrm{p}_{2} \mathrm{TiCl}$ in natural product synthesis. Top. Curr. Chem. 264, 63-91 (2006).

45. Gansäuer, A., Justicia, J., Fan, C.-A., Worgull, D. \& Piestert, F. Reductive C-C bond formation after epoxide opening via electron transfer. Top. Curr. Chem. 279, 25-52 (2007)

46. Justicia, J. et al. Bioinspired terpene synthesis: a radical approach. Chem. Soc. Rev. 40, 3525-3537 (2011).

47. Morcillo, S. P. et al. Recent applications of $\mathrm{Cp}_{2} \mathrm{TiCl}$ in natural product synthesis. Org. Chem. Front. 1, 15-33 (2014).

48. Hardouin, C., Chevallier, F., Rousseau, B. \& Doris, E. Cp $\mathrm{p}_{2}$ TiCl-mediated selective reduction of $\alpha, \beta$-epoxy ketones. J. Org. Chem. 66, 1046-1048 (2001)

49. Morcillo, S. P. et al. Ti(III)-catalyzed cyclizations of ketoepoxypolyprenes: control over the number of rings and unexpected stereoselectivities. J. Am. Chem. Soc. 136, 6943-6951 (2014).

50. Lan, J. et al. First total synthesis and absolute configuration of marine cembrane diterpenoid (+)-11,12-epoxysarcophytol A. Tetrahedron Lett. 41, 2181-2184 (2000).

51. Shibuya, M., Tomizawa, M., Suzuki, I. \& Iwabuchi, Y. 2-Azaadamantane N-oxyl (AZADO) and 1-Me-AZADO: highly efficient organocatalysts for oxidation of alcohols. J. Am. Chem. Soc. 128, 8412-8413 (2006).

52. Kuranaga, T. et al. Total synthesis and complete structural assignment of yaku'amide A. J. Am. Chem. Soc. 135, 5467-5474 (2013). 
53. Justicia, J., Jiménez, T., Morcillo, S. P., Cuerva, J. M. \& Oltra, J. E. Mixed disproportionation versus radical trapping in titanocene(III)-promoted epoxide openings. Tetrahedron 65, 10837-10841 (2009).

54. Paradas, M. et al. Understanding the exceptional hydrogen-atom donor characteristics of water in $\mathrm{Ti}^{\mathrm{III}}$-mediated free-radical chemistry. J. Am. Chem. Soc. 132, 12748-12756 (2010).

55. Snider, B. B. Manganese(III)-based oxidative free-radical cyclizations. Chem. Rev. 96, 339-364 (1996).

56. Snider, B. B., Mohan, R. \& Kates, S. A. Manganese (III) based oxidative freeradical cyclizations. 2 . Polycyclization reactions proceeding through tertiary cations. Tetrahedron Lett. 28, 841-844 (1987).

57. Zoretic, P. A., Weng, X., Biggers, M. S., Caspar, M. L. \& Davis, D. G. Manganese(III)-promoted oxidative free-radical cyclizations of $\beta$-keto imides: asymmetric induction with oppolzer's chiral sultam. Tetrahedron Lett. 33, 2637 (1992).

58. Zoretic, P. A., Fang, H. \& Ribeiro, A. A. Synthesis of d,l-norlabdane oxide and related odorants: an intramolecular radical approach. J. Org. Chem. 63, 4779-4785 (1998)

59. Barrero, A. F., Herrador, M. M., Quílez del Moral, J. F. \& Valdivia, M. V. A convenient synthesis of A-ring-functionalized podolactones. Revision of the structure of wentilactone B. Org. Lett. 4, 1379-1382 (2002).

60. Desai, L. V., Hull, K. L. \& Sanford, M. S. Palladium-catalyzed oxygenation of unactivated sp3C-H bonds. J. Am. Chem. Soc. 126, 9542-9543 (2004).

61. Neufeldt, S. R. \& Sanford, M. S. O-Acetyl oximes as transformable directing groups for Pd-catalyzed $\mathrm{C}-\mathrm{H}$ bond functionalization. Org. Lett. 12, 532-535 (2010).

62. Baldwin, J. E., Jones, R. H., Najera, C. \& Yus, M. Functionalization of unactivated methyl groups through cyclopalladation reactions. Tetrahedron 41, 699-711 (1985).

63. Zhu, C., Tang, P. \& Yu, B. Total synthesis of lobatoside E, a potent antitumor cyclic triterpene saponin. J. Am. Chem. Soc. 130, 5872-5873 (2008).

64. Del Valle, L., Stille, J. K. \& Hegedus, L. S. Palladium-catalyzed coupling of allylic acetates with aryl- and vinylstannanes. J. Org. Chem. 55, 3019-3023 (1990).

65. McNeil, D. W. et al. Novel non-nucleoside inhibitors of human immunodeficiency virus type 1 reverse transcriptase. 6. 2-indol-3-yl- and 2-azaindol-3-yl- dipyridodiazepinones. J. Med. Chem. 40, 2430-2433 (1997)

66. Im, G. J. et al. Indolyne experimental and computational studies: Synthetic applications and origins of selectivities of nucleophilic additions. J. Am. Chem. Soc. 132, 17933-17944 (2010).

67. Westermaier, M. \& Mayr, H. Electrophilic allylations and benzylations of indoles in neutral aqueous or alcoholic solutions. Org. Lett. 8, 4791-4794 (2006).

68. Klapars, A., Antilla, J. C., Huang, X. \& Buchwald, S. L. A general and efficient copper catalyst for the amidation of aryl halides and the $\mathrm{N}$-arylation of nitrogen heterocycles. J. Am. Chem. Soc. 123, 7727-7729 (2001).
69. TePaske, M. R., Gloer, J. B., Wicklow, D. T. \& Dowd, P. F. Tubingensin A: an antiviral carbazole alkaloid from the sclerotia of Aspergillus tubingensis. J. Org. Chem. 54, 4743-4746 (1989).

70. Reed, L. J. \& Muench, H. A simple method of estimating fifty percent endpoints. Am. J. Hyg. 27, 493-497 (1938).

\section{Acknowledgements}

We thank Professors N. Imamura and C. Zhang for providing the ${ }^{13} \mathrm{C}$ NMR spectrum of oridamycin A and an authentic sample of dixiamycin C, respectively. We are grateful to Professor Z.-J. Yao for his assistance with the cryoprobe NMR facility. Financial support was provided by Ministry of Science \& Technology (2013CB836900), National Natural Science Foundation of China (21290180, 21172235 and 21222202), Pujiang Program (12PJ1410800) and Chinese Academy of Sciences.

\section{Author contributions}

A.L. directed the project. A.L., Z.M., H.Y. and D.J.E. conceived the synthetic route. Z.M., H.Y., H.C. and M.W. conducted the synthetic work. L.L. and W.T. conducted the biological work. A.L., Z.M., H.Y., H.C., P.Y., D.J.E., L.L., W.T. and J.Z. analysed the results. A.L., D.J.E., L.L. and J.Z. wrote the manuscript.

\section{Additional information}

Accession codes: The X-ray crystallographic coordinates for structures (1, 6 and 40) reported in this Article have been deposited at the Cambridge Crystallographic Data Centre (CCDC), under deposition number CCDC 948203, 949054 and 948503. These data can be obtained free of charge from The Cambridge Crystallographic Data Centre via www.ccdc.cam.ac.uk/data_request/cif.

Supplementary Information accompanies this paper at http://www.nature.com/ naturecommunications

Competing financial interests: The authors declare no competing financial interest.

Reprints and permission information is available online at http://npg.nature.com/ reprintsandpermissions/

How to cite this article: Meng, Z. et al. Total synthesis and antiviral activity of indolosesquiterpenoids from the xiamycin and oridamycin families. Nat. Commun. 6:6096 doi: 10.1038/ncomms7096 (2015).

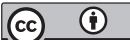

This work is licensed under a Creative Commons Attribution 4.0 International License. The images or other third party material in this article are included in the article's Creative Commons license, unless indicated otherwise in the credit line; if the material is not included under the Creative Commons license, users will need to obtain permission from the license holder to reproduce the material. To view a copy of this license, visit http://creativecommons.org/licenses/by/4.0/ 